$1-2012$

\title{
White Kids: Language, Race, and Styles of Youth Identity
}

Marcia Mikulak

University of North Dakota, marcia.mikulak@und.edu

How does access to this work benefit you? Let us know!

Follow this and additional works at: https://commons.und.edu/anth-fac

Part of the Anthropology Commons

\section{Recommended Citation}

Marcia Mikulak. "White Kids: Language, Race, and Styles of Youth Identity" (2012). Anthropology Faculty Publications. 3.

https://commons.und.edu/anth-fac/3

This Book Review is brought to you for free and open access by the Department of Anthropology at UND Scholarly Commons. It has been accepted for inclusion in Anthropology Faculty Publications by an authorized administrator of UND Scholarly Commons. For more information, please contact und.commons@library.und.edu. 
White Kids: Language, Race, and Styles of Youth Identity. Mary Bucholtz. New York: Cambridge University Press, 2011, 277 pp. \$33.99, paper.

White teenagers in the United States use everyday language to construct, alter, and perform their various identities, building their tropes on culturally constructed notions of gender, race, age, class, and cliques. Although tropes often refer to literary, figurative, or linguistic usages, Bucholtz demonstrates the power that teenagers have as social actors to construct meaning through the use of everyday linguistic practices. Fascinating and compelling, White Kids: Language, Race, and Styles of Youth Identity provides empirical qualitative research data that articulate the ways in which youth absorb and transform their local cultures, building on both constructive and destructive social norms.

The book consists of ten chapters and an abundance of rich and meaningful data in the form of figures, tables, and mapped social locations. Covering a broad range of sociolinguistic concerns, the book begins with a clear, jargon-free discussion about identity formations, social classifications, and assigned social categories among high school students at an urban high school in the San Francisco Bay area of California. The book succinctly demonstrates how identities are created by social actors during the artful practice of everyday social interactions.

Each chapter provides a type of clarity uncommon among academic research texts; the author's theoretical perspective is always clear, allowing her findings to pop with lucidity. Each component of this study prepares the reader for the rich and meaningful data provided by the research participants themselves. Local cultural contexts are revealed, methodologies and ethnographic processes are clarified, and teenage social categories are identified, problematized, and explored for socially meaningful lexical contexts.

Survey data used to gather key identifiers of identity among high school participants reveal interesting linguistic and other forms of symbolic artifacts that aid in understanding the constructions of high school youth identities. The impact of hip hop culture on white American boys demonstrates how African American male identities are appropriated to distinguish among various forms of white male identities, with the males retaining yet modifying their normative whiteness. Finally, Bucholtz broadens her focus as she explores how white students of all stylistic orientations at Bay City High School talked about race and racial tensions in terms of their local contexts.

What makes Bucholtz's work unique and important is its focus on speech displays that both articulate and confound racialized identities. Much appreciated by this reviewer is Bucholtz's focus on the complexities of identity formations, and the interactive social comingling that is required to form individual and collective group identities. In this sense, race, gender, age, ethnicities, social class, sexuality, and so on are determined by the interpenetration of all these categories. Bucholtz's research brings to the forefront a better understanding of the ways in which daily discourses shape our world and create our identities. Her insights can have a profound impact on how researchers and the public understand local interpersonal relationships and global, intercultural interactions between nation-states and various non-state actors.

For Bay City High School students, Bucholtz's findings demonstrate that identity is jointly produced (not individually constructed), that it is relationally meaningful yet honed and refined by acts of self-definitions and acts of defining otherness. Key to understanding this process is the realization that identity formations are processes of social actions, and not of individual states of being. Youths organize themselves into peer-based groups and social orders by drawing from adult-driven social structures. Bucholtz's findings suggest that youth are not 
primarily rebelling against the limitations and definitions of adult perceptions of and about them; instead the driving force behind youth identity formations and group cliques is for youth to identify with, and distinguish themselves from, their peers.

Youth performative styles are richly varied and complex, and they express meaning in terms of gender, ethnicity, sexuality, race, and social cliques. Hence, youth identities tend to be repetitive while modifying generational interpretations of social norms. The social context and location of high school students in Bucholtz's study are confounded by the institutional setting of American high schools - where students learn to navigate and negotiate white privilege and race relations within classroom and social settings. It is in such settings that students learn that whiteness is ideologically re-inscribed as normative unmarked, leading them to re-inscribe negative aspects onto the bodies of students of color. This study amplifies these topics by raising the volume on youth stylistic practices and performances of racialized identity formations.

While Burcholtz's study focuses on Euroamerican high school students, her findings and categories of analysis are applicable to identify formation studies in general. This study provides an example of how sociocultural linguistics can draw from the rich data available from an interdisciplinary coalition of fields, each of which focuses on the complex relationships among language, culture, and society. This book offers many valuable and insightful contributions to the study of socio linguistics and racialized identity formations while amplifying the study of agency, voice, and relations of power. In terms of the latter contributions just mentioned, it is the research practice of placing participants' viewpoints at the center of her analysis, and her commitment to remaining mindful of the agentive role of individual social actors that so greatly empowers Bucholtz's study. I highly recommend this text for all sociolinguists, but also stress its importance for all social science disciplines; for both researchers for their students.

Marcia Mikulak

University of North Dakota

Journal of Anthropological Research, vol. 68, 2012 